Maksymova I. G.

\title{
The Enzyme Membrain-Associated Complex Activity in Rat Brain under Imidazolin \\ Containing Organic Compounds Action
}

\author{
Kharkiv National Medical University, Kharkiv, Ukraine
}

\begin{abstract}
The aim of the study was to determine the $\mathrm{Na}^{+}, \mathrm{K}^{+}$-ATPase, adenylyl- and guanylyl cyclase synaptosome faction activity in the brain of rats at 30 day toxicity by imidazoline mixtures in $1 / 10$ and $1 / 100$ $\mathrm{LD}_{50}$ doses.

Materials and methods. The paper uses examples of MIM with alkyl radicals $C_{7-9}$ (MIM7-9) and $C_{9-15}$ (MIM9-15). Experiments carried out on the mature male rats Wistar, weighing 180-220 g. Maintenance and manipulation with animals were carried out according to the principles of bioethics. They were subjected to oral intoxification by probe using by aqueous solutions of compounds once daily per 30 days at a $1 / 100$ $\mathrm{LD}_{50}$ dose. Middle-lethal doses $\left(\mathrm{LD}_{50}\right)$ were: for MIM7$9-1,8 \mathrm{~g} / \mathrm{kg}$; MIM9-15 - 5,0 g/kg of body weight. The animals of the control group were injected by the corresponding volume of drinking water. The parameter study performed at 30 days after the start of the experiment. Each group contained 15 animals. Slaughter was performed by decapitation, with pre-anesthesia by sodium thiopental.
\end{abstract}

The $\mathrm{Na}+\mathrm{K}+$-ATP-ase, adenylyl and guanylyl cyclase activity in synaptosomal fraction of rat brain at 30th day of industrial chemical environmental pollutants - imidasoline mixtures influence have been studied in the paper to be necessary for full disclosure of biochemical mechanisms of membranotropic action. Imidasoline-containing mixtures with alkyl radicals C7.9 i C9-15 at 1/10 and 1/100 LD50 doses cause the change of membrane-associated enzyme activity to be confirmed by the decrease of $\mathrm{Na}+, \mathrm{K}+$-ATP-ase, adenylyl cyclase activity on the background of guanylyl cyclase increase. Revealed violations are one of pathogenetic links of biochemical mechanisms of imidasoline mixture membranotropic action to be considered in means of correction developing.

Summarizing the results, it should be made the following conclusions. Against the background of prolonged toxicity by MIM in 1/10 and $1 / 100$ LD $_{50}$ doses synaptosome fraction of rat brain membrane enzyme activity is changing, as evidenced by decreased activity of $\mathrm{Na}^{+}, \mathrm{K}^{+}$-ATPase, adenylyl cyclase on the background of increasing guanylyl cyclase. Change of membrane-associated enzyme complexes activity in the brain of rats is one of the pathogenetic mechanism of links membrane tropic MIM action to be considered when developing the means of correction.
Keywords: imidasoline mixtures, rats, brain, microsomes, $\mathrm{Na}+\mathrm{K}+-$ ATP-ase, adenylyl cyclase, guanylyl cyclase.

Work is the fragment of SRW «Біохімічні механізми розвитку дисметаболічних процесів за умов впливу хімічних чинників навколишнього середовища», State Registration № 0115 U000240.

Inroduction. Actual problem of modern medical biochemistry is a comprehensive studying of the mechanisms of xenobiotic action on humans and means of correction development $[7,5]$. Common xenobiotics able adversely affect health, include a imidazoline mixture (MIM). This is associated with large volumes of chemicals, widely used in various sectors of the economy (as the basis for industrial production of detergents, antistatic, anticorrosive agents, adhesive additives, etc.), revenues of the sources of drinking water [1, 4, 14]. The clinical picture of rata cute poisoning by MIM is proved to be the symptoms of the central nervous system disorders in the foreground [14]. Furthermore, electron microscopy studies indicate significant changes architectonics of the nervous tissue, including violation of the integrity of neurons under conditions of prolonged rat intoxication by MIM [14]. Lack of information about the biochemical mechanisms of MIM action on the body encourages them to conduct a comprehensive study, starting primarily with state of the central nervous system. Given the physical and chemical properties of MIM components (the presence of hydrophobic and hydrophilic groups, capacity for chemical reactions to form biologically active compounds, etc.), it is reasonable to research their influence on some characteristics of cell membranes, including membrane-associated enzyme complexes.

The aim of the study was to determine the $\mathrm{Na}^{+}$, $\mathrm{K}^{+}$-ATPase, adenylyl- and guanylyl cyclase synaptosome faction activity in the brain of rats at 30-day toxicity by imidazoline mixtures in $1 / 10$ and $1 / 100 L_{50}$ doses.

Materials and methods. The paper uses examples of MIM with alkyl radicals $C_{7-9}$ (MIM7-9) and $C_{9-15}$ (MIM9-15). Experiments carried out on the mature male rats Wistar, weighing 180-220 g. Maintenance and manipulation with animals were carried out according to the principles of bioethics. They were subjected to oral intoxification by probe using by aqueous solutions of compounds once daily per 30 days at a $1 / 100 L_{50}$ dose. Middle-lethal doses $\left(\mathrm{LD}_{50}\right)$ were: for MIM7-9 - 1,8 g/kg; 
MIM9-15 - 5,0 g/ $\mathrm{kg}$ of body weight. The animals of the control group were injected by the corresponding volume of drinking water. The parameter study performed at 30 days after the start of the experiment. Each group contained 15 animals. Slaughter was performed by decapitation, with pre-anesthesia by sodium thiopental.

The $\mathrm{Na}^{+}, \mathrm{K}^{+}-$ATPase activity in synaptosome fraction of rat brain was evaluated by the difference between the content of inorganic phosphorus in the absence and presence in the incubation medium $1 \mathrm{mM}$ uabayine accordance with the methodical recommendations [6]. The samples were put to incubation medium containing $100 \mathrm{mM} \mathrm{NaCl}, 20 \mathrm{nM} \mathrm{KCl}, 50 \mathrm{nM}$ tris- $\mathrm{HCl}$ (pH 7,6), 3 $\mathrm{mM} \mathrm{MgCl}_{2}, 0,5 \mathrm{mM} \mathrm{CaCl}_{2}, 0,5 \mathrm{mM}$ EDTA, $3 \mathrm{mM}$ ATP. The incubation was carried out at $37^{\circ} \mathrm{C}$ per 30 minutes; The reaction was stopped by the addition of $15 \%$ trichloroacetic acid. Precipitation of denatured proteins was performed at $3500 \mathrm{~g}$ per 10 minutes. For synaptosome fraction extraction the tissue was homogenated in 50 $\mathrm{mM}$ tris- $\mathrm{HCl}$ buffer $(\mathrm{pH} 7,5)$ with $5 \mathrm{mM}$ theophylline та 4 $\mathrm{mM} \mathrm{MgCl}$ at cold in glass hemegenisator (80 up/down); homogenate was centrifugated at $1500 \mathrm{~g}$ at $4^{\circ} \mathrm{C}$ during 5 minutes, supernatant was centrifugated at $18000 \mathrm{~g}$ at $0-4^{\circ} \mathrm{C}$ during 30 minutes, final clot was rehomogenisated in $1,5 \mathrm{ml}$ of the same buffer [2]. Adenylyl cyclase activity $(A C)$ in synaptosome fraction was determined by method [15], guanylyl cyclase (GC) - by method [13]. The enzyme activity was judged about by the accumulation of the products of enzymatic reactions - cAMP and cGMP. The incubation medium for AC activity determination contained $50 \mathrm{mM}$ tris- $\mathrm{HCl}$ buffer $(\mathrm{pH} 7,5), 5 \mathrm{mM}$ creatine phosphokinase, and for GC determination - 50 $\mathrm{mM}$ tris- $\mathrm{HCl}$ buffer ( $\mathrm{pH} 7,5), 10 \mathrm{mM}$ theophylline, $4 \mathrm{mM}$ $\mathrm{MgCl}_{2}, 4 \mathrm{mM}$ creatine phosphate, $0,1 \mathrm{mg} / \mathrm{ml}$ creatine phosphokinase. Substrates responses were prepared at concentrations: АТФ - $2 \mathrm{mM}$, ГТФ - $1 \mathrm{mM}$.

Statistical analysis was performed using the computer application package for the processing of statistical information Statistica 6. 1 (StatSoft, Inc., USA). In the case of the normal distribution of data parametric characteristics - the average indicator (M) and standard deviation (s) were used; in its absence nonparametric - median (Me) and interquartile scope. The critical level of significance during testing statistical hypotheses was accepted $p<0,05$.

Results and discussion. The groups of rats undergoes oral administration per 30 days by MIM in 1/10 LD ${ }_{50}$ dose observed statistically significant $(p \leq 0,005)$ compared with the control decrease $\mathrm{Na}^{+}, \mathrm{K}^{+}$-ATPase activity of synaptosome fraction of the brain by an average of $37 \%$ (table 1). Prolonged exposure by MIM79 in $1 / 100 L_{50}$ dose was also accompanied by statistically significant relative to the control group of animals, decrease enzyme activity, but less pronounced (at $16 \%$ ) than the $1 / 10 L_{50}$ dose. Comparison between a distribution rate in the group of animals administered by MIM915 in a $1 / 100 L_{50}$ dose, and the control did not show any statistically significant difference $(p=0,065)$.
Table 1

$\mathrm{Na}^{+}, \mathrm{K}^{+}$-ATPase activity in synaptosome fraction of rat brain at $30^{\text {th }}$ day of imidazolin containing organic mixture influence ( $\mu \mathrm{mol} \mathbf{P}_{\mathrm{i}} / \mathbf{h} \cdot \mathbf{m g}$ of protein, $n=15 ; \operatorname{Me}[25 \% ; 75 \%]$ or $M \pm s$ )

\begin{tabular}{|l|c|c|}
\hline \multirow{2}{*}{ Mixture } & \multicolumn{2}{|c|}{ Dose, LD $_{\mathbf{5 0}}$} \\
\cline { 2 - 3 } & $\mathbf{1 / 1 0}$ & $\mathbf{1 / 1 0 0}$ \\
\hline \multirow{2}{*}{ MIM7-9 } & $\begin{array}{c}8,2 \pm 2,21 \\
\mathrm{p}<0,001\end{array}$ & $\begin{array}{c}12,3[7,9 ; 13,7] \\
\mathrm{p}=0,014\end{array}$ \\
\hline \multirow{2}{*}{ MIM9-15 } & $\begin{array}{c}10,4[7,7 ; 13,4] \\
\mathrm{p}=0,005\end{array}$ & $\begin{array}{c}12,1 \pm 2,82 \\
\mathrm{p}=0,065\end{array}$ \\
\hline Control & \multicolumn{2}{|c|}{$14,6 \pm 3,60$} \\
\hline
\end{tabular}

Note: $p$ - level of significance compared with control.

At the 30th day of observation in synaptosome fraction of rat brain statistically significant $(p<0,001)$ compared with the control reducing the activity of adenylyl cyclase (AC) was also found (table 2). 1/10 LD dose thus was more toxic than 1/100 LD ${ }_{50}$. MIM7-9 and MIM9-15 in 1/10 LD ${ }_{50}$ dose reduced $A C$ activity in relation to the control, respectively 58 and $50 \%$, and in a $1 / 100 L_{50}$ dose -41 and $26 \%$. On the background these changes, there was a statistically significant increased activity of guanylate cyclase (GC). The most expressive effect $(p<0,001)$ at the same time MIM7-9 commit: on $88 \%$ (in the case of $1 / 10 L_{50}$ ) and $66 \%$ (in the case of $1 / 100 L_{50}$ ). For MIM9-15 in 1/10 LD 50 dose increase $(p \leq 0,002) \mathrm{GC}$ activity was $54 \%$, and in a dose $1 / 100$ LD50 - $32 \%$.

Thus, studies have found changes in the activity of membrane-associated enzyme complexes in the brain of rats under prolonged exposure by MIM. The main reasons of this can be a direct effect on enzyme complexes or structural changes in membranes (especially due to free radical processes). Previous experiments have demonstrated that MIM $1 / 10$ and $1 / 100$ LD $_{50}$ doses at 30th day actions cause the ratio of plasma membrane phospholipid fractions changes significantly increasing the percentage of phospholipids lysoform [10] and increase microviscosity of lipid phase [9],

Table 2

Adenylyl and guanylyl cyclase activity in rat brain at $30^{\text {th }}$ day of imidazolin containing organic mixture influence ( $\mathrm{n}=15 ; \mathrm{Me}[25 \% ; 75 \%]$ or $\mathrm{M} \pm \mathrm{s}$ )

\begin{tabular}{|c|c|c|c|c|}
\hline \multirow{3}{*}{ Mixture } & \multicolumn{2}{|c|}{$\begin{array}{l}\text { Adenylyl cyclase, } \\
\text { pmol cAMP/min-mg of } \\
\text { protein }\end{array}$} & \multicolumn{2}{|c|}{$\begin{array}{c}\text { Guanylyl cyclase, } \\
\text { pmol cAMP/min-mg of } \\
\text { protein }\end{array}$} \\
\hline & \multicolumn{4}{|c|}{ dose, LD $_{50}$} \\
\hline & $1 / 10$ & $1 / 100$ & $1 / 10$ & $1 / 100$ \\
\hline MIM7-9 & $\begin{array}{c}42,3 \pm 5,59 \\
p<0,001\end{array}$ & $\begin{array}{c}59,7[51,8 ; \\
69,0] \\
p<0,001\end{array}$ & $\begin{array}{c}136,2[128,6 \\
160,3] \\
p<0,001\end{array}$ & $\begin{array}{c}120,2 \\
{[112,3} \\
135,2] \\
p<0,001\end{array}$ \\
\hline $\begin{array}{l}\text { MIM9- } \\
15\end{array}$ & $\begin{array}{c}50,8[49,0 \\
57,7] \\
p<0,001\end{array}$ & $\begin{array}{c}75,2 \pm 9,41 \\
p<0,001\end{array}$ & $\begin{array}{c}111,7 \pm 24,62 \\
p<0,001\end{array}$ & $\begin{array}{c}95,6[80,3 ; \\
99,5] \\
p=0,002\end{array}$ \\
\hline Control & \multicolumn{2}{|c|}{$101,5 \pm 13,69$} & \multicolumn{2}{|c|}{$72,4[68,4 ; 79,5]$} \\
\hline
\end{tabular}

Note: $p$ - level of significance compared with control. 
which naturally leads, according to many experimental studies $[8,11]$, to reduce the activity of membrane associated enzymes.

The composition of the membranes of all cells as integral protein that converts the energy of ATP to energy gradient of monovalent ions is an enzyme $\mathrm{Na}^{+}$, $\mathrm{K}^{+}$-ATPase. It should be noted that this enzyme is involved into numerous cellular functions and processes associated with ion gradients, particularly in providing the electrical excitability of nervous tissue [3]. Therefore, changes in the activity of this enzyme by MIM actions could become an essential reason for their violation. Reducing adenylyl cyclase and increase guanylyl cyclase activity are also a consequence of studied membrane tropic of MIM. As you, The elements of adenylyl cyclase and guanylyl cyclase complexes are known to be integral membrane proteins that's why AC and GC activity are most dependent on the cell membrane [12]. In addition, GC can be activated by free radicals, lipid peroxides, which increased formation is observed in the organism of experimental animals under prolonged exposure by MIM [4].

Summarizing the results, it should be made the following conclusions.

1. Against the background of prolonged toxicity by MIM in $1 / 10$ and $1 / 100 L_{50}$ doses synaptosome fraction of rat brain membrane enzyme activity is changing, as evidenced by decreased activity of $\mathrm{Na}^{+}, \mathrm{K}^{+}$-ATPase, adenylyl cyclase on the background of increasing guanylyl cyclase.

2. Change of membrane-associated enzyme complexes activity in the brain of rats is one of the pathogenetic mechanism of links membrane tropic MIM action to be considered when developing the means of correction.

Perspectives further research. In future the complex research conduction is planned aimed to study the biochemical mechanisms of MIM, including evaluation of antiradical activity and antyperoxid protection.

\section{References}

1. Bajpai D. Fatty imidazolines, chemistry, synthesis, properties and their industrial application / D. Bajpai, V. K. Tyagi // Journal of Oleo Science. - 2006. - Vol. 55, № 7. - P. 319-329.

2. Hajos F. An improved method for preparation of synaptosomal fractions in high purity / F. Hajos // Brain Res. - 1975. Vol. 93. - P. 485-489.

3. Scheiner-Bobis G. The sodium pump. Its molecular properties and mechanisms of ion transport / G. Scheiner-Bobis // Eur. J. Biochem. - 2002. - Vol. 269. - P. 2424-2433.

4. Tyagi R. Imidazoline and its derivatives: an overview / R. Tyagi, V. K. Tyagi, S. K. Pandey // Journal of Oleo Science. - 2007. Vol. 56, № 5. - P. 211-222.

5. Грузєва Т. С. Вплив екологічних чинників на формування глобального тягаря хвороб / Т. С. Грузєва // Науковий вісник Національного медичного університету ім. О. О. Богомольця. - 2010. - № 27. - С. 167-168.

6. Казеннов А. М. Исследование активности Na, К-АТФазы в эритроцитах млекопитающих / А. М. Казеннов, М. Н. Маслова, А. Д. Шалабодов // Биохимия. - 1984. - № 7. - С. 1089-1094.

7. Ксенобіотики: накопичення, детоксикація та виведення з живих організмів / [Б. О. Цудзевич, О. Б. Столяр, І. В. Калініна та ін.]. - Тернопіль : Видавництво ТНТУ ім. І. Пулюя, 2012. - 384 с.

8. Курский М. Д. Біомембранологія / М. Д. Курский, С. М. Кучеренко. - К. : Вища школа, 1993. - 200 с.

9. Максимова І. Г. Мікров'язкість мембран клітин крові щурів за дії імідазолінвмісних органічних сумішей / І. Г. Максимова // Зб. матер. науково-практ. конф. : Здобутки клінічної та експериментальної медицини. - Тернопіль, 2013. - С. 163164.

10. Максимова І. Г. Фосфоліпідний склад мембран еритроцитів щурів за умов впливу імідазолінвмісних органічних сумішей / І. Г. Максимова // Зб. матер. науково-практ. конф. : Довкілля та здоров'я. - Тернопіль. 2013. - С. 112-114.

11. Огурцов А. Н. Биологические мембраны / А. Н. Огурцов. - Х. : НТУ «ХПИ», 2012. - 368 с.

12. Федоров Н. А. Циклические нуклеотиды и их аналоги в медицине / Н. А. Федоров, М. Г. Радуловацкий, Г. Е. Чехович. М. : Медицина, 1990. - 176 с.

13. Чирков Ю. Ю. Гуанилатциклаза тромбоцитов крови человека / Ю. Ю. Чирков, И. А. Тыщук, Н. Н. Белушкина // Биохимия. - 1987. - Т. 52, Вып. 6. - С. 956-963.

14. Эколого-гигиеническая характеристика азотсодержащих поверхностно-активных веществ как загрязнителей водоемов / [В. И. Жуков, В. В. Мясоедов, С. А. Стеценко и др.]; под ред. В. И. Жукова. - Х. : Торнадо, 2000. - 180 с.

15. Юдаев Н. А. Активность аденилатциклазы и содержание циклических нуклеотидов в опухолях надпочечников человека при синдроме Иценко-Кушинга / Н. А. Юдаев, С. А. Афиногенова, К. Н. Казеев // Биохимия. - 1981. - Т. 46, Вып. 1. - С. 55-61.

\section{УдК 577. 352. 334:[616. 831-099:543. 395]-092. 9 АКТИВНІСТЬ ФЕРМЕНТНИХ МЕМБРАНОЗВ'ЯЗАНИХ КОМПЛЕКСІВ У ГОЛОВНОМУ МОЗКУ ЩУРІВ ПРИ ДІЇ ІМІДАЗОЛІНВМІСНИХ ОРГАНІЧНИХ СУМІШЕЙ Максимова І. Г.}

Резюме. У роботі вивчено активність $\mathrm{Na}^{+}, \mathrm{K}^{+}$-АТФази, аденілат- і гуанілатциклази у синаптосомальній фракції головного мозку щурів на 30-ту добу впливу промислових хімічних забруднювачів довкілля - сумішей імідазоліні, що є необхідним для всебічного розкриття біохімічних механізмів мембранотропної дії. Імідазолінвмісні суміші з алкільними радикалами $\mathrm{C}_{7-9}$ i $_{9-15}$ у дозах 1/10 і 1/100 LD мембранозв'язаних ферментів, що підтверджується зниженням активності $\mathrm{Na}^{+}, \mathrm{K}^{+}$-АТФази, аденілатциклази 
на тлі підвищення гуанілатциклази. Виявлені порушення є однією з патогенетичних ланок біохімічних механізмів мембранотропної дії сумішей імідазолінів, що необхідно враховувати при розробленні засобів їх корекції.

Ключові слова: суміші імідазолінів, щури, головний мозок, мікросоми, $\mathrm{Na}^{+}, \mathrm{K}^{+}$-АТФаза, аденілатциклаза, гуанілатциклази.

УДК 577. 352. 334:[616. 831-099:543. 395]-092. 9

АКТИВНОСТЬ ФЕРМЕНТНЫХ МЕМБРАНОСВЯЗАННЫХ КОМПЛЕКСОВ В ГОЛОВНОМ МОЗГЕ КРЫС ПРИ ВОЗДЕЙСТВИИ ИМИДАЗОЛИНСОДЕРЖАЩИХ ОРГАНИЧЕСКИХ СМЕСЕЙ

\section{Максимова И. Г.}

Резюме. В работе изученаактивность $\mathrm{Na}^{+}, \mathrm{K}^{+}$-АТФазы, аденилат- и гуанилатциклазы в синаптосомальной фракции головного мозга крыс на 30-е сутки воздействия промышленных химических загрязнителей окружающей среды - смесей имидазолинов, что необходимо для всестороннего раскрытия биохимических механизмов мембранотропного действия. Имидазолинсодержащие смеси с алкильными радикалами $\mathrm{C}_{7-9}$ и $\mathrm{C}_{9-15}$ в дозах 1/10 и 1/100 LD что подтверждается снижением активности $\mathrm{Na}^{+}, \mathrm{K}^{+}$-АТФазы, аденилатциклазы на фоне повышения гуанилатциклазы. Выявленные нарушения являются одним из патогенетических звеньев биохимических механизмов мембранотропного действия смесей имидазолинов, что необходимо учитывать при разработке способов их коррекции.

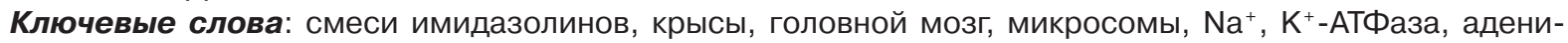
латциклаза, гуанилатциклаза.

Стаття надійшла 06. 11. 2015 p. 